\title{
Reuna
}

\section{THE ROLE OF RESILIENCE IN THE CREATION OF MEANINGFUL WORK FOR YOUNG BRAZILIAN WORKERS, VICTIMS OF MORAL HARASSMENT}

\author{
O PAPEL DA RESILIÊNCIA NA CONSTRUCCÃO DO SIGNIFICADO DO \\ TRABALHO PARA JOVENS BRASILEIROS VIITIMAS DE ASSÉDIO MORAL
}

\author{
http://dx.doi.org/10.21714/2179-8834/2020v25n2p53-69
}

\author{
Alice de Freitas Oleto \\ Escola de Administração de Empresas de São Paulo (FGV/EAESP), Brasil. \\ E-mail: aliceoleto@hotmail.com \\ Diego de Sousa Guerra \\ Escola de Administração de Empresas de São Paulo (FGV/EAESP), Brasil. \\ E-mail: diegoguerra@gmail.com \\ José Vitor Palhares \\ Universidade Federal de Minas Gerais (UFMG), Brasil. \\ E-mail: titopalhares@hotmail.com \\ Kely César Martins de Paiva \\ Universidade Federal de Minas Gerais (UFMG), Brasil. \\ E-mail: kelypaiva@face.ufmg.br
}

Submissão: 03 Jun. 2020. Publicação: 30 Jun. 2020. Sistema de avaliação: Double blind review. Centro Universitário UNA, Belo Horizonte - MG, Brasil. Editor geral: Prof. Dr. Thiago Soares Nunes

Este artigo encontra-se disponível nos seguintes endereços eletrônicos:

http://revistas.una.br/index.php/reuna/article/view/1163

http://dx.doi.org/10.21714/2179-8834/2020v25n2p53-69

\begin{abstract}
This study aims to analyse the role of resilience in the behavior of young workers who suffered moral harassment, from the perspective of professionals from a vocational training association. Thus, a case study is of a descriptive nature and was carried out using a qualitative approach. Interviews were conducted with 21 professionals from this association, whose data underwent content analysis. It should be noted that the research initially aimed to interview the young workers assisted by the association, but direct contact with them was prohibited. It has been noted that moral harassment can be recognised when sudden behavioural changes are observed in young people suffering from this kind of aggression. Changes such as self-isolation, silence, introspection, quietude, or they consider aggression against them as if it were a joke. It has also been noted that young people tend to be resilient against aggression they have suffered in an effort to keep their jobs, whether out of necessity or out of gratitude. Finally, the consequences of moral harassment that affect the personal and professional lives of young people the most are demotivation, impairment of work performance, loss of the pleasure of working, low self-esteem and psychological problems. Therefore, it is important to develop and implement actions against violence in the work environment, and a healthy environment for the workers.
\end{abstract}

Keywords: Moral Harassment; Resilience; Young Workers; Workplace.

REUNA, Belo Horizonte - MG, Brasil, v.25, n.2, p. 53-69, Abr. - Jun. 2020 - ISSN 2179-8834 


\section{Resumo}

Este estudo objetivou analisar o papel da resiliência no comportamento de jovens trabalhadores que vivenciaram o assédio moral, pela percepção dos profissionais de uma associação de ensino profissionalizante. Assim, realizou-se um estudo de caso, de natureza descritiva e abordagem qualitativa. Foram feitas entrevistas com 21 profissionais da referida associação, cujos dados foram submetidos à técnica de análise de conteúdo. Ressalte-se que a pesquisa tinha como objetivo inicialmente entrevistar os jovens trabalhadores assistidos pela associação, mas o contato direto com eles foi proibido. Percebeu-se que o assédio moral é percebido por meio de mudanças de comportamento dos jovens quando eles sofrem esse tipo de agressão, tais como isolamento, silêncio, introspecção, quietudes, ou levar as agressões na brincadeira. Também percebeu-se que os jovens tendem a ser resilientes frente às agressões sofridas para manterem seus empregos, seja por necessidade seja por gratidão. Por fim, as consequências do assédio moral que mais afetam a vida pessoal e profissional dos jovens são a desmotivação, o prejuízo ao desempenho no trabalho, a perda do prazer de trabalhar, além de baixa autoestima e problemas psicológicos. Assim, é importante que se desenvolvam e se apliquem ações contra a violência no ambiente do trabalho, promovendo um clima e ambiente saudável para os seus trabalhadores.

Palavras-chave: Assédio Moral; Resiliência; Jovens Trabalhadores; Local de Trabalho.

\section{Introduction}

Talking about moral harassment and resilience in organizations is pertinent in order to raise questions about consent, submission and freedom of individuals. Moreover, it calls our attention to how people see meaning in their work, even after the suffering aggression.

According to Codo (1997, p. 26), work presupposes "a relation of double transformation between man and nature, which generates meaning". It is through work that the relation between subject and object becomes meaningful. The meaning transcends, remaining beyond the subject and object relationship, the more complete and complex this relationship, the greater the pleasure of work (CODO, 1997). Giddens (2007) states that work, intrinsic to every economic system, is a way for people to meet their needs.

But often, to become competitive, companies use practices that harass workers, disrespecting them in the workplace, such as moral harassment. The harassment occurs as a result of individual pathological behaviors, notably focused on the harasser, and also because of broader contexts that facilitate and even promote their occurrence, such as economic-organizational pressures for productivity and competitiveness, permissive cultures and fragile or absent legal-institutional structures (PAIVA, 2019; PAIVA et al., 2019). People become very fragile because of these attacks, which affect their emotional conditions, causing damage, often irreversible (NUNES, TOLFO, 2013; PAIVA, 2019), as well as deteriorating socio-productive relationships (KANAN, ZANELLI, 2018).

These results can be enhanced when they are associated with issues of diversity and discrimination, such as differences in skin color, gender (PELLEGRINI et 
al., 2017; MOURA, CAMPOS, 2019), disability (OLETO, SILVA, PAIVA, 2016), among others. Other targets of these aggressions in the workplace are the young worker. They are considered a special population, with different interests, aspirations and needs when compared to groups of more experienced professionals (TUCKER, LOUGHLIN, 2006). However, there are few studies on the work experience of this group of workers in the Administration field, even less on unpleasant or dysfunctional experiences at work, as is the case with moral harassment.

As for moral harassment, this is a phenomenon that purposefully deteriorates the working conditions of the person. This happens on the part of colleagues, usually unprepared managers, who want, at any cost, to increase productivity and results (DEJOURS, 1993; BARRETO, 2003).

It is, therefore, a serious and extreme process of psychological violence, which happens continuously and repeatedly in the context of work, which humiliates, offends and embarrasses.

In the daily routine, moral harassment occurs in the form of recurrent, disturbing, rude and hostile practices, through action or omission (exclusion), embodied in gestures, words (written or spoken) and explicit, camouflaged/silent behaviors or procedures (SOBOLL, 2006). Guedes (2008) describes this abuse as a "psychoterror", in which the victim is caught in a trap without even knowing why.

On resilience, in behavioral sciences, studies have identified it as the ability of an individual or group, even in an unfavorable environment, to build or rebuild themselves positively in the face of adversity (BARLACH, 2005).

For Jackson, Firtko and Edenborough (2007), resilience is a state, or process, individual, group or in a community that can be defined as the ability to adapt to adversity, maintain balance, retain some sense of control over their environment and continue to move forward in a positive way.

From the standpoint of positive psychology, examining how some people can have a positive outcome and are therefore stronger after going through some form of workplace aggression can help in the development of workers and more resilient workplaces (HEUGTEN, 2012).

Many young people, even suffering from moral harassment at work, continue to be employed, mainly because of the salary they receive and the fear of being unemployed for a long time, as pointed out by Silva and Nakata (2016).

Thereby, the objective of this research was, from the perspective of the professionals of a vocational education institution, to analyse the role of resilience in the behavior of young workers who experienced moral harassment. This institution operates throughout Brazil, promoting the inclusion of young workers in situations of social vulnerability in the labor market. The institution forbade interviews with the young workers being assisted and requested confidentiality on their identification.

Finally, the relevance of doing a study on the moral harassment suffered by young workers and how they can be resilient in relation to the aggression experienced has the following motives: first, because of the importance of young people in society and how we can use their experiences to help train the working masses; secondly, because the proposed theme would be a contribution to academia , since it is relatively recent, with little research available on moral harassment of young, resilient workers; 
also considering the difficulties of researching a subject so delicate and important for people and organizations. In addition, this research may generate the possibility of exposing a part of the reality of this public that can be considered in policies and practices of people management in the organizations that shelter it.

\section{Theoretical reference}

\subsection{Moral Harassment}

Moral harassment has different connotations, depending on culture and context, but the use of this term is growing rapidly in various social spaces. Therefore, the term "moral harassment" is becoming known to the worker and, consequently, to society as a whole.

The author who first identified the phenomenon of moral harassment was Leymann (1990), using the term "mobbing". Hirigoyen (2006), precursor of the term "moral harassment", disseminated and denounced the phenomenon by explaining that harassment in workplace is linked to any abusive conduct towards a person that could cause damage to either their personality or their dignity, even their physical or mental integrity, and may lead to loss of employment or degradation of the work environment in which the victim is positioned.

The hostile attitudes characterised by moral harassment were classified into four general categories by Hirigoyen (2011): purposeful deterioration of working conditions, exclusion and refusal of communication, outrage against dignity; and verbal, physical and sexual violence. In Brazil, other studies and scholars on the subject confirm and reinforce these characteristics (NUNES; TOLFO, 2013; OLETO; SILVA; PAIVA, 2016; PELLEGRINI et al., 2017; KANAN; ZANELLI, 2018, MOURA; CAMPOS, 2019; PAIVA, 2019; PAIVA et al., 2019).

Regarding types of moral harassment, the phenomenon can be found in six forms in organizations: horizontal, vertical ascending, vertical descending, mixed, strategic and collective. Horizontal moral harassment is practiced by the colleagues of the victim and occurs when the harasser has trouble dealing with differences. Vertical ascending harassment is characterized by being 'subordinated' by the subordinate in relation to his superior position, and although less frequent, it does occur and can be as harmful to people as other types of harassment (GUEDES, 2008). Vertical descending moral harassment is the type conducted by the hierarchical superior against the subordinate and is considered the most frequent. Mixed harassment, according to Hirigoyen (2011), occurs when the subordinate is simultaneously attacked by superiors and colleagues, and in this case, what one has is the so-called group effect, which causes the group to follow the leader, even though their behavior is pernicious. In strategic, moral harassment, organizations act to lead employees away from their activities, having as their main characteristic the exclusionary character used by the hierarchy as the main element in the relationship between the aggressor and the victim (GUEDES, 2008). Collective moral harassment occurs against a group or community of employees of the company and is characterized by punishments to employees who do not reach the determined goals (MELO, 2008).

Thus, although there are several forms of expression, moral harassment has negative and varied consequences. According to Caixeta (2010), moral harassment at work has the objective of degradation of working conditions, the endangerment of the 
rights and dignity of workers, the alteration of their physical or mental health, as well as compromising their future career.

\subsection{Resilience}

Resilience can be defined as the capacity that a human being, alone or as part of a social group, has, to recover psychologically when subjected to adversity and abuse, facing them, being transformed by them, and surpassing them at the end (PINHEIRO, 2004).

Resilience also refers to an active process that conforms to positive adaptation within the context of significant adversity (GOLDSCHMIDT; PAIVA; IRIGARAY, 2019). It can be understood through two essential conditions: 1) exposure to significant threat or severe adversity; 2) the achievement of favored positive adaptation through major advances in the development process (LUTHAR; CICCHETTI; BECKER, 2000).

Grotberg (2005) suggests that resilient behavior reveals the commitment of an individual to developing their ability to confront, win, and emerge strengthened from adverse situations.

According to Conner (1995), it is possible to identify five important characteristics of resilience: positivity, proactivity, organization, focus and flexibility. Positivity and proactivity induce change rather than avoid it. Organization makes it possible to manage multiple tasks simultaneously and more quickly. Focus is the result of clear and objective vision. And flexibility responds to uncertainties, where resilient individuals manage change, knowing how to recover quickly.

In addition, resilience is supported on two bases: the first is adversity, represented by the unfavorable events of life; and the second is protection, which is indicated by the understanding of the forms of support, both internal and external to the individual, leading to a particular reconstruction in the face of suffering caused by a mishap (ASSIS, 2006).

Another aspect associated with resilience is the transformation that emerges when faced with a traumatic or adverse situation. In fact, human resilience causes human beings to restructure themselves psycho-emotionally seeking, through subjectivity and creativity, a new way of interacting with the environment (BARLACH, 2005).

\subsection{Young Workers}

The presence of young people in the workforce has been encouraged by society, including being encouraged through state and federal government policies, expressed by the First Job, Young Citizen, My First Work and other programs (FISCHER et al., 2003a).

In addition to public policies and programs, the early entry of young people into work is legalised by Brazilian legislation, Law 10.097/00 (BRAZIL, 2000), known as the "Law of Learning", which amended the Consolidations of Labor Laws to deal with legal matters relevant to the hiring of apprentices. This law provides these apprentices with labor and social security rights, as well as the right to access and attend school. 
Despite that, according to Thomé, Telmo and Koller (2010), the insertion of young people in the world of work has occurred in an increasingly precarious way, especially in labor contexts marked by informality and unemployment. In general, the entry of young workers into this market begins with more fragile and transitory occupational ties, until the establishment of a bond that is more durable or, at least, legally protected.

Thus, work can be a risk to young people as it can lead to certain types of exposure and/or experiences that can cause harm to their physical and/or psychic integrity. In this sense, Frone (2000) believes that it is important to identify and manage the characteristics of youth work. Working conditions can negatively affect professional attitudes and mental health, considering that young workers, who are still developing cognitively, emotionally and socially, may have fewer resources to deal with traumatic experiences and are likely to suffer significant effects, including harmful consequences for their future.

The perception of forms of psychological or physical harassment in the work environment by young people can facilitate the identification and prevention of these situations and their consequences, given that, in the face of this configuration of the world of work, the youth may find themselves on a career path that is meaningless to them, placing them in forms of work which are degrading, alienating and deprived of real learning opportunities, precisely at the moment in which they are defining their personal and occupational personality.

Thus, the experience of young people in the job market reflects a certain contradiction that will influence the career and personal lives of these individuals, because, on the one hand, there is the importance of this work for young people as a positive moral value for development psychosocial, the construction of their identities, the financial guarantee to buy consumer goods, the sense of responsibility for helping the family and the possibility of acquiring experience and learning (FRANCO et al. 2018); on the other hand, there are also negative consequences resulting from early exposure to physical and psychological loads, such as the impairment of the schooling process due to tiredness and lack of time, increased levels of stress, excessive responsibility and the experience of certain types of violence in the workplace (FISCHER, 2003b; KLUG et al., 2019).

In this context, Oliveira and Godoy (2015) highlight the importance of an effective resilience process among young workers to deal with situations of vulnerability and adversity and to overcome them, since, according to the authors, the positive aspects attributed to work in adolescence override the negatives. Therefore, it is necessary to understand the different forms of occurrence of psychological and physical violence or moral harassment in the workplace by young people, as well as the different ways they use to face these types of violence at work, such as the resilience process (OLETO et al., 2020), since the way in which they deal with these experiences can bring reflexes to the adult and to the professional being trained (OLETO et al., 2018).

\section{Methodology}

To achieve our objective, a study with a qualitative approach was carried out, as this type of research proposes to understand the meanings and situational 
characteristics presented by the subjects in detail, rather than the production of quantitative measures of characteristics or behaviors (RICHARDSON et al., 1999). As for the ends, the descriptive nature was chosen, following Cervo and Bervian (2002, p. 66), for whom "descriptive research observes, registers, analyses and correlates facts or phenomena (variables) without manipulating them". A case study was made, which was intentionally restricted to only a few subjects, so we could achieve more depth and detail (VERGARA, 2006).

The subject of analysis was Association $\mathrm{X}$, a non-profit organization that gives vulnerable young people professional training enabling them to participate in the Brazilian labor market, as it has centres throughout the nation. In this study, the Belo Horizonte (MG) centre, Brazil, focused on accessibility criteria, it was implemented with the formal authorisation and intent of the management, we were given access to informants who spend each day with young people, many of them under 18, and have access to various types of their complaints (VERGARA, 2006). It is worth mentioning that, initially, direct contact with the young workers was attempted to reach the objective of the research, however, there was no reply from Association $X$, as previously it had definitively denied us any contact with the youth, stating any contact could expose these young professionals. Finally, an agreement was reached and confidentiality was agreed regarding the identification of the interviewees and that the association itself, would be referred to as Association X.

Thus, the research subjects were 21 professionals from Association X, 14 instructors, 3 analysts, 1 social worker, 1 psychologist and 2 coordinators. The institution was selected for accessibility and intentionality.

During the data collection, the interview was chosen with a semi-structured script that was divided into two parts. The first part collected socioeconomic information from the interviewees and the second part focused on the moral harassment itself, with direct and objective questions on how such professionals saw the daily work of young people, and specific situations of moral harassment.

Finally, the interviews were analysed considering the technique of content analysis, based on a qualitative discourse, with reliability and validity as concerns (BAUER; GASKELL, 2005). All interviews were recorded and transcribed.

\section{Data analysis and results}

Among the interviewees, the majority were female (80.95\%), between 31 and 40 years old $(33.33 \%)$, single $(52.38 \%)$, with a postgraduate degree $(57.15 \%)$, with a family income of 5 to 7 minimum wages (33.33\%), and with a working time of 3.1 to 5 years (47.61\%) at Association $X$.

Most professionals interviewed at Association X stated that young people do not understand or know what the term 'moral harassment' means, which makes it difficult to identify situations of harassment as well as differentiating them from specific facts such as more incisive demands and other actions of psychological and / or physical violence.

They do not know. In speech you see that they do not know, many think it is ... it's just a form of hierarchy, that he can talk to me like that because he's the boss, he owns the company. A few have some guidance after someone tells 
him that might be harassment, but most of the time they are not aware of it. (E2).

Such misunderstanding can contribute to the repetition of specific actions that end up being characterized in a process of harassment, perpetuating such practices against young people in organizations. It's the same with interviewed E9, E4, E15 and E18 that said "No. Unfortunately, they are very limited - some, we cannot,... errrm, generalize, but let me think better ... a lot of them do not have much of a concept of this issue, the term, and in what situation to use it. "(E9); "I, I do not even know if they ... if I can figure out if they know, if they know what that is." (E4); "I cannot tell you what they know, but I realize they are aware of it." (E15); and "I have not yet had the opportunity to identify this in the young people I dealt with, no. From their perception of moral harassment. I have not had the opportunity yet" (E18).

When asked if Association X professionals had informed them of any situations of moral harassment, like offenses, embarrassment or disrespect at work, most of them said yes.

In some cases, yes, the young person feels, right, embarrassed, yes, already. It's ... and then they use that term a lot: 'ah, my manager today called me to talk' or not, right, 'exposed me in front of my colleagues and talked about my hair', for example, 'is that he does not like my haircut and that he thought it best I cut it and even asked the other one there, is that, right, 'cut, do not cut'. So, this is the type, of course, situation. (E5)

Look, I've seen it from a colleague, right? And then we guide the person to talk to the manager, right? Flag what's happening, right? Sometimes on behalf of the boss too, right? And then when you go to see this situation is not only with the young person, the person is like that, the profile of it, right? Sometimes drier, more aggressive in the way of talking, you know? (E19)

We observe the same understanding in the statements "In some cases, depending on the audience with whom they work, the nickname's own play even hurts. Those who talk the most are usually colleagues, not the boss ..." (E11) and "More about that, about ... about ... turning around and saying that they're just apprentices, something like that ... And it comes from the boss, or it's from employees themselves, so they work with them and such" (E14).

Attitudes such as having an employee cut their hair for not seeing it as handsome, putting malicious nicknames, or diminishing the person for what they are or for the position or function they perform can be classified as hostile attitudes of moral harassment (HIRIGOYEN, 2011). The first two attitudes are considered outrage against dignity of the victim and the third is considered a purposeful deterioration of working conditions of the victim. From the interviewees' statements, it can be inferred that these attitudes towards young workers are not punctual, and thus are cases of moral harassment, as reported in other studies on the topic (HIRIGOYEN, 2011; PAIVA et al., 2019) and with such a group of workers (OLETO et al., 2018, 2020).

In addition, it was possible to identify three types of moral harassment. The first type identified was vertical descending moral harassment in which the offender was hierarchically superior (E5). The second identified type was horizontal moral harassment in which the aggressor (s) were (s) work colleague (E11). And the third type of moral harassment identified was mixed harassment in which the perpetrators were both superior hierarchical and co-workers (E14 and E19). 
As for moral harassment, when asked how a situation of harassment is perceived involving a young person in the daily life of the association, most reported that young people change their behavior:

\begin{abstract}
Wow, we're very perceptive. The young worker is usually very communicative. For example, they arrive and sometimes you approach a subject and that young man who is talkative, changes, he becomes quieter. You approached the subject, he did not express very well, we already notice that there is something different. (E7)

I see ... I see them more reactive than they are standing still. [...] Normally the young worker gets a little more aggressive, he disagrees with everything he says. That "ah, in the company is this, that" and you already see that it is not, and already raises a flag totally against ... (E20)

It is possible to identify this also in the speech of interviewed E19: "Ah! They end up getting a little different right? So, in behaviour, right? Sometimes it is, is, more isolated, not wanting to participate, more inhibited. So, you must investigate" (E19).
\end{abstract}

The behavioural change of a worker, whether they are young or not, because of moral harassment, is the initial consequence of the so-called entanglement phase (HIRIGOYEN, 2011). In this phase, the victim has not yet recognised himself as being a victim of moral harassment, only feeling conflicted and in doubt, because situations end up transforming his work into constant torment. It is at this stage that the victim begins to feel the effect of the stress, caused by a great inner tension. They also begin to feel fear and are permanently on alert, they react more rudely, have a glacial tone in their voice, generating suppressed aggression, entering a phase of isolation, in which the victim begins to doubt their own perceptions, not being sure of what they are seeing (HIRIGOYEN, 2011). In the case of young workers, these facts can have a direct impact on the meanings they attribute to their work, as well as on the forms of reaction and resistance they develop, damaging a positive identity with work and with the organization.

Anyway, in the interviews, it can be noted that the young people identified by the interviewees are in this phase of entanglement since, as said by the professionals approached, they choose to isolate themselves, become quieter or tend to become more aggressive.

As for the motivation of the young workers to maintain and give meaning to the work in the organization where moral harassment occurred, it was noticed in the interviewees' reports that young workers see employment as an opportunity, thus having a feeling of gratitude for Association $X$ and the affiliated organization they are working for.

It reports, in a positive way, they have an environment that is ... it is very receptive to their formation, and it is even possible to perceive this because when we visit the companies we know the spaces. Where they carry out the activities. (E16)

Look... catching on for the majority, they get very attached to the gratitude of being in the job market. Especially today with the market in crisis. They, too, cling to it ... to the gratitude of being working and helping at home. Even our audience, which is a vulnerable audience. So, the income, thus, makes up the family income. (E1)

They are amazed. They: "Oh, I'm working!" And, we have many reports too: sometimes humble father, humble mother. Young, thus, having a position in a 
company... enters as an apprentice having a chance to make a career in the company and... leaves here, from house in a suit, neat and such to work in companies that require it. So, they have, is ... a vision, right, of even an improvement in life. (E2)

Usually they talk about the opportunity and the managers who are always there to explain things, accomplish tasks, some doubts that hit them regarding the events of the day and what they did in response. So, they come to ask or to question what can be done differently, what initiatives they need to implement on these issues within these organizations. (E11)

This understanding is exemplified by the following statements "But it's ... in the opportunities I had to be with young people, they are motivated. By work ... most of the time." (E18); "Yes, they usually feel good in the company where they are." (E10); "So, they like to work, when they have problems, because they like the work, they really do comment, because they see that there is something that does not... for them anyway, it is working." (E12); and "So, they like to work, when they have problems, because they like the work, they really do comment, because they see that there is something that does not... for them anyway, it is working" (E12). Some authors deal with these processes of reframing in the work environment, of transforming suffering into pleasure in order to maintain a certain psychic integrity and maintain levels of motivation for work. However, a distorted formation of a young worker can lead to the formation of perverse personalities in the future, that is, in the specialized workforce of the future, which is worrying in terms of professional career (FRANCO et al., 2018; OLETO et al., 2018; PAIVA, 2019).

This feeling of motivation may emerge from the fact that, today, attaining a position in the labor market is not the easiest task. According to Pereira and Pinto (2004), with an extremely competitive job market and unwelcoming professional prospects, demands for qualifications are part of the reality that the young workers must confront.

The interviewees stated that the permanence of the young person in work is motivated by the need for maintenance and a career opportunity. So, they tend to give more of themselves at work, so they do not lose that job. They feel compelled to develop personally and professionally, even thinking of a chance to be hired permanently or promoted, as observed by Franco et al. (2018).

In addition, these attitudes corroborate the understanding of Sarriera et al (2001), since, for the young, working class workers, gainful employment represented, and it seems still represents, the possibility of transforming their social reality for a better future.

Almeida and Silva (2004) reinforce this understanding by reporting that young people view work as protection against being marginalized and involvement in criminal activity, representing an alternative for their livelihood and/or for their family. In addition, reports indicate that young workers believe that without the help of Association $\mathrm{X}$ they would not have the chance to work for the types of companies they do.

What is perceived is that young workers, even suffering moral harassment at work, continue in their jobs, motivated mainly by the salary they receive and the fear of being unemployed for a long time, as Silva and Nakata's (2016) study pointed out. It is seen here, as young workers give meaning to their work, besides presenting a resilient behavior, since it is possible to perceive the young person's commitment to 
develop their capacity to face, win and leave strengthened from adverse situations (GROTBERG, 2005; OLETO et al., 2020).

In this way, it is possible to see how young workers tend to be resilient in the face of the aggression suffered to keep their jobs, either out of necessity, gratitude, or both (FRANCO et al., 2018).

In addition, even people who develop a degree of resilience are not immune to the behavioural changes that may occur consequently.

As for the consequences of moral harassment in the personal and professional life of the young workers, the professionals interviewed emphasise the fact that the young people feel demotivated.

\begin{abstract}
It is demotivation, behavior change, a young person who is very interested that ends up not having more commitment with the work, whit the punctuality, so I think that mainly changes the behavioral issue and some psychological even (E3).

Suddenly, on the professional side they think they can grow, that they can be someone, if they really have this harassment, they will lose their motivation, then they will go to ways other than the path of ethics, the way of... the correct way that they should. So, the issue of motivation is what is most affected (E6).
\end{abstract}

It was also possible to note that many of the young workers work performance is impaired and they no longer take pleasure in their work. "It interferes in their development and professional growth ... it can even freeze them" (E4).

\begin{abstract}
So, I see that the young worker, who cannot steady himself or ask for help, is, in this situation, they end up becoming passive, isolation is this and it even hinders their development, because they are so afraid that they end up not proving themselves. So, I see that in the general character on the issue of harassment, it for this reason that the person ends up isolating themselves. (E9)

A development that could be good, is, much smaller than expected. Maybe they would not have the space where they saw the confidence to develop some, some point to improve, and, basically, their professional development is harmed. What we notice. (E15)

It's a really emotional question. They are ... to feel, a matter of self-esteem, a question of their development. This can detract from their own performance in the company. With that ... their question of trust in people, in the confidence of the professional themselves that they want to be. (E16)
\end{abstract}

In their personal life, young workers may suffer from low self-esteem and psychological problems, like some appointments of interviewed: "not wanting to work or staying indoors, leading to depression depending on... the, harassment and exposure it causes." (E4); "Psychological consequences... Psychological damage... relationship, is... in the work itself, or can impair performance... ultimately demotivation, health issues, can harm health." (E10); "And... same emotional question. Of... they are... feeling, a matter of self-esteem, a question of their development... The emotional consequences, too. Of... being stuck. Of reproach, of... shyness, of much." (E16); and "Ah, complicated. I think it can directly affect self-esteem, self-confidence. (They) Do not want to work or stay indoors, leading to a depression depending on ... the, harassment and exposure..." (E4). These issues were discussed in the study by Barbosa and Paiva (2020) and may signal other sources of suffering to be considered in the management of this group of people in the organizations where they work. 
All these cases corroborate the consequences that moral harassment can have on the lives of young workers. With moral harassment, repeated humiliating, degrading treatment, persecution or offense occur in such a way as to reduce the self-esteem of the victim, leading to mental imbalance and stress. Mental health and, often, even physical, is compromised, generating or aggravating diseases. These are called psychosomatic diseases. There is also a tendency for the harassed to become effectively unproductive, but not because of their personal and functional qualities, but simply because of the harassment.

In this sense, Schmidt (2002) exemplifies various effects of moral harassment such as self-condemnation, feelings of uselessness and failure, decreased productivity, increased absenteeism, dismissal, the weakening of health, and tension in affective relationships, and a lack of any real solution, which can end up leading the already hopeless victim to lose the will to live.

Salvador (2002) presents the effects of moral violence as a destructive process that can lead the victim to permanent incapacitation and even to death: the so-called 'bullicide'. Aggression tends to trigger anxiety, and the victim becomes defensive because he or she feels threatened and, in addition, feelings of failure and impotence become frequent.

Finally, regarding the way in which cases such as these are treated in Association $X$, it was noticed through the reports that, when the facts become clear to the professionals of the institution, there is usually transfer or dismissal of the young person from the company:

\begin{abstract}
A removal, a transfer from the company, there was also an older case here that I remember now, this was also the issue of sexual harassment and we managed to... why is it like this? when the young workers sign the contract. they lose the right to be an apprentice again. And in this case, how a situation like this happened, that we needed the contract to be closed for the girl to leave the company, to protect her, we got authorisation from the Ministry of Labor for her to be re-assigned to another company. (E18)
\end{abstract}

First thing is to remove the young worker from the company, when it is already something like that, it is noted, likewise, the young woman reported that the manager tried to grab her, kiss her inside the company. When the young woman reported, the first step was to get the young woman out of the company. (E17)

Thus, it is possible to see that, when sexual or moral harassment takes place in these organizations, one of the direct consequences for the young professionals is their dismissal or transfer, as stated by the scholars of the subject (FREITAS, 2001), as a way of "protecting" the subject-victim. These young victims, who have been through an embarrassing situation within the organization and who have suffered abuse, are transferred or removed from the organization. However, nothing was quoted by the interviewees as to what happens to the perpetrator in these cases, demonstrating that harassment often goes unpunished within organizations. Thus, questions about inclusion and insertion of young workers leave other blurry points, in addition to the analysis by Franco et al. (2018), as well as those related to the career, as suggested by the resilience literature (GOLDSCHMIDT; PAIVA; IRIGARAY, 2019), especially of young workers (OLETO et al., 2020).

This fact may contribute to the victims not denouncing those who practice abuse, since if they denounce, their jobs and benefits may be threatened, which is 
referenced by scholars of the subject (SANTOS, 2002), as being justified by the assumption of "protection", and because they do not see punitive measures for the aggressor, according to their understanding. These issues involving impunity are common in Brazil and seem to be part of a national culture that facilitates and even promotes the occurrence of violence such as harassment, which should be considered in a multilevel analysis of the phenomenon of harassment (PAIVA, 2019; PAIVA et al., 2019).

\section{Conclusion}

This study aimed to analyses the role of resilience in the behavior of young workers who experienced moral harassment, from the viewpoint of the professionals of a vocational, educational institution.

As a result, it was verified that the interviewees showed that they did not understand the concept of moral harassment, which they said was common among young people.

Moral harassment can be identified through behavioral changes of young when they suffer this type of aggression. The young workers identified by the interviewees are in the so-called "entanglement phase" whereby they choose to be isolated, becoming quieter and introspective, or pretending to understand the aggression as a joke. According to those interviewees, these young workers have not yet become aware that they are victims of moral harassment, despite the discomfort and doubt about their working conditions, because these situations end up transforming their work into a constant torment. At this stage, the victim begins to feel the effects of the stress caused by a great inner tension, reacting with veiled attacks, becoming isolated, and in which they begin to doubt their own perceptions, not being sure of their own feelings. Such data collected at Association X corroborate the literature that deals with the phenomenon of harassment in the workplace.

On the subject of the desire to remain in the organization where harassment took place, and of what their work means to them, it is important to highlight the difficulties involved in finding their place in the labor market, especially considering the turbulent political-economic crisis that the country is going through. Therefore, young workers tend to be committed at work in order to maintain employment. They feel compelled to develop personally and professionally, even hoping for a chance to be hired as a full-time employee or get a better position. The interviewees affirmed that the permanence of the young people in employment is motivated by a desire to maintain the position and by career opportunity. Young workers see these first work experiences as a great opportunity in their lives, thereby feeling gratitude for Association $X$ and the affiliated organization they are working for. Thus, it is possible to see how and why young people tend to be resilient in the face of the aggression suffered to keep their jobs, either out of necessity or out of gratitude.

In addition, even people who develop resilience are not immune to the consequences that may occur in their behavior. Respondents reported that the consequences of moral harassment that most affect the personal and professional lives of young people are demotivation, impairment of work performance, loss of the pleasure of working, low self-esteem and psychological problems. 
Lastly, regarding how harassment cases are treated in Association $\mathrm{X}$, we gathered, through the reports that when the professionals of the institution become aware of them, the young worker is transferred or removed from the company, compounding the possible consequences of moral harassment, since no actions related to the organization are reported.

The fact is that organizations need to effectively develop and implement actions aimed at eliminating or reducing the risks that involve incidents of aggression in their internal environments, thus promoting a healthy environment for their workers.

\section{Referências}

ALMEIDA, M. M.; SILVA, R. C. Compreendendo as estratégias de sobrevivência de jovens antes e depois da internação na FEBEM. Revista Brasileira de Orientação Profissional, v. 5, n. 1, p. 87-102, 2004.

ASSIS, S. G. Superação de dificuldades na infância e adolescência: conversando com profissionais de saúde sobre resiliência e promoção da saúde. Rio de Janeiro: FIOCRUZ/ENSP/CLAVES/CNPq, 2006.

BARBOSA, J. K. D.; PAIVA, K. C. M. Temos todo tempo do mundo? Estudo sobre Percepções Temporais, Prazer e Sofrimento com Jovens Trabalhadores. FOCO (Faculdade Novo Milênio), v. 13, n. 1, p. 04-30, 2020.

BARLACH, L. O que é resiliência humana? Uma contribuição para a construção do conceito. Dissertação (Mestrado em Psicologia). Instituto de Psicologia da Universidade de São Paulo, São Paulo, 2005.

BARRETO, M. M. S. Violência, saúde, trabalho: uma jornada de humilhações. São Paulo: EDUC, 2003.

BAUER, M. W.; GASKELL, G. Pesquisa qualitativa com texto, imagem e som: um manual prático. 4. ed. Petrópolis, RJ: Vozes, 2005.

BRASIL. Lei n. 10.097, de 19 de dezembro de 2000. Altera dispositivos da Consolidação das Leis do Trabalho - CLT, aprovada pelo Decreto-Lei n. 5.452, de 1ํ de maio de 1943. Brasília: Diário Oficial da União, 2000.

CAIXETA, I. C. O assédio moral nas organizações: um estudo nos Tribunais Regionais do Trabalho das regiões Sudeste e Sul do Brasil. 2010. 153fs. Dissertação (Mestrado em Administração) - Faculdade Novos Horizontes, Belo Horizonte.

CERVO, A, L.; BERVIAN, P. A. Metodologia científica. 5. ed. São Paulo: Pearson Prentice Hall, 2002.

CODO, W. O que é alienação? 8. ed. São Paulo: Brasiliense, 1992.

CONNER, D. R. Gerenciamento na velocidade da mudança. Rio de Janeiro: Infobook, 1995. 
DEJOURS, C. A loucura do trabalho: estudo de psicopatologia do trabalho. 5. ed. São Paulo: Cortez Oboré, 1993.

FISCHER, F. M. et al. Occupational accidents among middle and high school students of the state of São Paulo, Brazil. Revista de Saúde Pública, v. 37, n. 3, p. 351-56, $2003 a$.

FISCHER, F. M. et al. Efeitos do trabalho sobre a saúde de adolescentes. Ciênc. saúde coletiva, São Paulo, v. 8, n. 4, p. 973-984, $2003 \mathrm{~b}$.

FRANCO, D. S.; MAGALHÃES, A. F.; PAIVA, K. C. M.; SARAIVA, L. A. S. Entre a inserção e a inclusão de minorias nas organizações: Uma análise crítica sob o olhar de jovens trabalhadores. E\&G - Revista Economia e Gestão, v. 17, n. 48, p. 43-61, 2018.

FREITAS, M. E. Assédio moral e assédio sexual: faces do poder perverso nas organizações. Revista de Administração de Empresas, v. 41, n. 2, p. 8-19, 2001.

FRONE, M. R. Interpersonal conflict at work and psychological outcomes: testing a model among young workers. Journal of Occupational Health Psychology, v. 5, n. 2, p. 246-55, 2000.

GIDDENS, A. Sociologia. 4. ed. Porto Alegre: Artmed, 2007.

GOLDSCHMIDT, C. C.; PAIVA, K. C. M.; IRIGARAY, H. A. R. Organizational Resilience: Proposition for an Integrated Model and Research Agenda. Tourism \& Management Studies, v. 15, n. 3, p. 37-46, 2019.

GROTBERG, E. H. Introdução: Novas tendências em resiliência. In: MELILLO, A; OJEDA, E. N. S. e colaboradores. Resiliência: descobrindo as próprias fortalezas. Porto Alegre: Artmed, 2005. p. 15-22.

GUEDES, M. N. Terror psicológico no trabalho. 3. ed. São Paulo: LTR, 2008.

HEUGTEN, K. V. Resilience as an Underexplored Outcome of Workplace Bullying. Qualitative Health Research v. 23, n. 3, p. 291 - 301, 2012.

HIRIGOYEN M. F. Mal-estar no trabalho: redefinindo o assédio moral. 6. ed. Rio de Janeiro: Bertrand Brasil, 2011.

HIRIGOYEN, M. F. Assédio moral: a violência perversa no cotidiano. 8. ed. Rio de Janeiro: Bertrand Brasil, 2006.

KANAN, J. C.; ZANELLI, L. A. Fatores de risco e de proteção psicossocial: organizações que emancipam ou que matam. Lages: Editora da Uniplac, 2018.

KLUG, K.; BERNHARD-OETTEL, C.; MÄKIKANGAS, A.; KINNUNEN, U.; SVERKE, $M$. Development of perceived job insecurity among young workers: a latent class growth analysis. International Archives of Occupational and Environmental Health, v. 92, p. 901-918, 2019. 
LEYMANN, $H$. Mobbing and psychological terror at workplaces. Violence and Victims, v. 5, n. 2, p. 119-26, 1990.

LUTHAR, S. S.; CICCHETTI, D.; BECKER, B. The construct of resilience: a critical evaluation and guidelines for future work. Child Development, v. 71, n. 3, p. 543-562, 200.

MELO, N. D. Assédio moral: individual e coletivo. Âmbito Jurídico, Rio Grande, v. 11, n. 54, 2008. Disponível em: <https://ambitojuridico.com.br/edicoes/revista-54/assediomoral-individual-e-coletivo/>. Acesso: 15 fev. 2018.

MOURA, R. G.; CAMPOS, C. M. A. "O Assédio Sexual, Ele Deixa Cheiro, Ele Deixa Cor, Ele Deixa Nojo": o estabelecimento da precariedade subjetiva por meio do assédio sexual. In: ENCONTRO ANUAL DA ASSOCIAÇÃO NACIONAL DE PÓSGRADUAÇÃO E PESQUISA EM ADMINISTRAÇÃO, 53, 2019, São Paulo. Anais... São Paulo: ANPAD, 2019.

NUNES, T. S.; TOLFO, S. R. Assédio moral em universidade: as possíveis consequências em comentar e/ou denunciar a violência. Administração Pública e Gestão Social, v. 5, n. 4, p. 144-151, 2013.

OLETO, A. F.; SANTOS, J. V. P.; PAIVA, K. C. M.; BARBOSA, J. K. D. Estratégias de Enfrentamento de Jovens Trabalhadores diante das Relações Abusivas de Poder nas Organizações. Revista Alcance Eletrônica, v. 27, n. 1, p. 99-113, 2020.

Oleto, A.; PAlHARES, J. V.; PAIVA, K. C. M.; GUIMARÃES, L. R. Percepções De Tutores Sobre $O$ Assédio Sexual Sofrido Por Jovens Trabalhadores Nas Organizações. Revista Gestão.Org, v. 16, n. 1, p. 43-56, 2018.

OletO, A. F.; SILVA, A. G. C.; PAIVA, K. C. M. Assédio Moral e Pessoas com Deficiência: um Estudo de Processos do Tribunal Superior do Trabalho ou Encontros entre a Diversidade e o Abuso. In: ENCONTRO ANUAL DA ASSOCIAÇÃO NACIONAL DE PÓS-GRADUAÇÃO E PESQUISA EM ADMINISTRAÇÃO, 50, 2016, Costa do Sauípe. Anais... Costa do Sauípe: ANPAD, 2016.

OLIVEIRA, A. L. de; GODOY, M. M. da C. O processo de resiliência do jovem aprendiz e as estratégias de conciliação estudo-trabalho. Boletim de Psicologia, v. 65, n. 143, p. 175-191, jul. 2015.

PAIVA, K. C. M. Gestão de Recursos Humanos: teorias e reflexões. Curitiba: Intersaberes, 2019.

PAIVA, K. C. M., et al. Shedding light on hidden violence: harassment in Brazilian organizations. In: EGOS COLLOQUIUM, 35, 2019, Edinburgh. Anais... Edinburgh: EGOS, 2019.

PELLEGRINI, P. G., et al. Assédio moral no trabalho contra mulheres servidoras públicas. In: ENCONTRO DE GESTÃO DE PESSOAS E RELAÇÕES DE TRABALHO, 6, 2017, Curitiba. Anais... Curitiba: ANPAD, 2017. 
PINHEIRO, D. P. N. A resiliência em discussão. Psicologia em Estudo, v. 9, n. 1, p. 67-75, 2004. Disponível em: <http://www.scielo.br/pdf/pe/v9n1/v9n1a09>. Acesso: 15 fev. 2018.

RICHARDSON, R. J. et al. Pesquisa social: métodos e técnicas. 3. ed. São Paulo: Atlas, 1999.

SALVADOR, L. Assédio moral. Direito e justiça. O Estado do Paraná S/A, Curitiba, p. 8-9, 2002.

SANTOS, A. Assédio sexual nas relações trabalhistas e estatuárias. 2. ed., Rio de Janeiro: Forense, 2002.

SARRIERA, J.C; SILVA, M. A; KABBAS, C. P; LOPES, V. B. Formação da identidade ocupacional em adolescentes. Estud. psicol. (Natal) [online]. v. 6, n. 1, p. 27-32, 2001.

SCHMIDT, M. H. F. M. O assédio moral no direito do trabalho. Revista do Tribunal Regional do Trabalho da 9a Região, Curitiba, Serviço de Biblioteca e Jurisprudência, v. 27, n. 47, p. 177-227, jan./jun. 2002.

SILVA, V. V.; NAKATA, L. E. Da deterioração das relações à escolha pela permanência: o assédio moral no trabalho. ReCaPe - Revista de Carreiras e Pessoas, v. 6, n. 2, p. 206-214, 2016.

SOBOLL, L. A. P. Violência psicológica e assédio moral no trabalho bancário. 2006. 214 fs. Tese (Doutorado em Medicina Preventiva) - Faculdade de Medicina da Universidade de São Paulo, São Paulo.

THOMÉ, L. D.; TELMO, A. Q.; KOLLER, S. H. Inserção laboral juvenil: contexto e opinião sobre definições de trabalho. Paidéia, v. 20, n. 46, p. 175-85, 2010.

TUCKER, S.; LOUGHLIN, C. Young workers. In: KELLOWAY, E. K.; BARLING, J.; HURRELL, J. (eds.). Handbook of Workplace Violence. Thousand Oaks: Sage, 2006. p. 417-444.

VERGARA, S. C. Métodos de pesquisa em administração. 2. ed. São Paulo: Atlas, 2006. 